\title{
Success and failures in the inoculation of five introduced trees in Chile with Tuber magnatum Pico: First advances for the domestication of the white truffle in South America
}

\author{
Éxitos y fracasos en la inoculación de cinco especies arbóreas introducidas en Chile con Tuber \\ magnatum Pico: Primeros avances en la domesticación de la trufa blanca en Sudamérica
}

\section{Guillermo Pereira ${ }^{1}$, Götz Palfner ${ }^{2}$, Laura M. Suz ${ }^{3}$, Patricio Sandoval ${ }^{1}$, Ricardo Ramírez ${ }^{4}$, Daniel Chávez ${ }^{1,5}$, Cristian Atala ${ }^{6, *}$}

'Departamento de Ciencias y Tecnología Vegetal, Campus Los Ángeles, Universidad de Concepción, Escuela de Ciencias y Tecnologías, Los Ángeles, Chile. ²Departamento de Botánica, Facultad de Ciencias Naturales y Oceanográficas, Universidad de Concepción, Casilla 160-C, Concepción, Chile.

${ }^{3}$ Comparative Plant and Fungal Biology. Royal Botanic Gardens Kew, Richmond Surrey, TW9 3DS, UK.

${ }^{4}$ Andean Truffles SPA. Parcela 5 Santa Ana, Mulchén-Chile.

${ }^{5}$ Centro de Investigación en Micorrizas y Sustentabilidad Agroambiental, CIMYSA. Universidad de La Frontera, Av. Francisco Salazar 01145, Temuco, Chile. ${ }^{6}$ Instituto de Biología, Facultad de Ciencias, Pontificia Universidad Católica de Valparaíso, Campus Curauma, Avenida Universidad 330, Valparaíso, Chile.

*E-mail: cristian.atala@pucv.cl

\section{ABSTRACT}

Truffles are highly demanded edible fungi. They belong to the genus Tuber and have very high economic value, with Tuber magnatum being one of the most expensive and gastronomically used. This study evaluates the potential of five introduce tree species as mycorrhizal hosts for T. magnatum in Chile. Seeds from Quercus cerris, Q. robur and Corylus avellana were harvested from adult trees. Cuttings from Populus nigra and Salix caprea were harvested in the field and asexually propagated under greenhouse conditions. After two months, they were transplanted to $260 \mathrm{cc}$ pots containing sterilized composted pine bark. A spore suspension ( $10^{6}$ spores/plant) of T. magnatum was injected directly into plant roots. Three months after inoculation we observed spore germination and the presence of mycelium around the roots in some seedlings. After seven months, we observed mycorrhizae from T. magnatum only in Q. cerris, Q. robur and C. avellana, characterized by their epidermoid mantle and awl-shaped, bristle-like cystidia. The identification the mycorrhizal structures was confirmed by sequencing of the nuclear ITSrDNA region. This study provide the first advances for the domestication of this highly valuable truffle in Chile and South America and the successful mycorrhized plants could be used in further field assays. Some Quercus, Populus and Salix species have been used as ornamental plants and are naturalized in Chile for over 100 years. Additionally, hazelnut (Corylus avellana) is currently grown in the country under intensive silviculture. These tree species could act as a non-intentional host for truffles, dispersed from production sites.

Keywords: Corylus avellana, ITS-rDNA, mycorrhizal synthesis, Quercus cerris, Q. robur, white truffles.

RESUMEN

Las trufas son hongos comestibles muy demandados. Pertenecen al género Tuber, siendo de alto valor económico, con Tuber magnatum uno de los más caros y usados gastronómicamente. Aquí se evaluó el potencial de cinco especies arbóreas introducidas como huésped de T. magnatum en Chile. Semillas de 
Quercus cerris, Q. robur y Corylus avellana fueron recolectadas de árboles adultos. Segmentos de Populus nigra y Salix caprea se recolectaron en terreno y propagaron asexualmente en invernadero. Luego de dos meses, se trasplantaron a potes de 260 cc con compost de corteza de pino esterilizado. Luego, se inyectó una suspensión esporal ( $10^{6}$ esporas/planta) de T. magnatum directamente en las raíces. Tres meses después, se observó germinación de las esporas y micelio alrededor de las raíces en algunas plántulas. Luego de siete meses, se observaron micorrizas de T. magnatum solo en Q. cerris, Q. robur y C. avellana, caracterizadas por su manto epidermoide y cistidios en forma de aguja. La identificación de las estructuras micorrícicas se confirmó con secuenciación de la región nuclear ITS-rDNA. Este estudio provee los primeros avances para domesticar esta trufa altamente valiosa en Chile y Sudamérica, y las plantas exitosamente micorrizadas podrían usarse en futuros ensayos de campo. Algunas especies de Quercus, Populus y Salix se usan en Chile como plantas ornamentales, naturalizadas desde hace más de 100 años. Adicionalmente, el avellano europeo (Corylus avellana) se cultiva en el país bajo silvicultura intensiva. Estas especies arbóreas podrían actuar como huéspedes no intencionales de trufas, dispersadas desde lugares de producción.

Palabras clave: Corylus avellana, ITS-rDNA, Quercus cerris, Q. robur, síntesis micorrícica, trufa blanca.

\section{INTRODUCTION}

Truffles are edible fungi with unique aromas (Mello et al. 2001; Paolocci et al. 2006). The genus Tuber includes 180 to 230 species distributed worldwide (Bonito \& Smith 2016) and around 30 of them in Europe (Reyna 2000; De Miguel \& Reyna 2007; Gregori 2007). Not all truffle species have culinary value and only approximately a dozen species have commercial interest (Bonito et al. 2010). Among them, Tuber magnatum Pico (Italian white truffle or Piedmont truffle), Tuber melanosporum Vittad. (Périgord black truffle), Tuber aestivum Vittad. (summer or Burgundy truffle) and Tuber borchii Vittad. (bianchetto truffle) hold the highest gastronomic value, with $T$. magnatum and T. melanosporum reaching the highest values in international markets (Hall et al. 2007; Zambonelli et al. 2010; Salerni et al. 2014; Reyna \& García-Barreda 2014; Zambonelli et al. 2015). In France, Italy, Spain and Australia truffles are currently a multi-million industry (Reyna \& García-Barreda 2014). Along their natural distribution, truffles are not only harvested in the wild but also in plantations using truffle inoculated seedlings (Reyna \& García-Barreda 2014). Truffles not only harbor and economical value but also important social and ecological value (Benucci et al. 2012a) living in mycorrhizal symbiosis with the roots of suitable host plants (Paolocci et al. 2006; Zambonelli et al. 2012a; Bonito et al. 2013). Tuber spp. were thought to only form ectomycorrhizae (Zambonelli et al. 2015), but recently they have been found forming arbutoid mycorrhizae (Lancelloti et al. 2014), endomycorrhizas in orchids (Selosse et al. 2004) and they might also act as a root endophytes in non-ectomycorrhizal plants (Schneider-Maunoury et al. 2018).
Truffles naturally grow in areas with a particular weather, soil and vegetation, like those of the Mediterranean Europe (Reyna \& De Miguel 2007, Sáez \& De Miguel 2008). The loss and deterioration of their natural habitats (Benucci et al. 2012a) due to the reduction of traditional practices, overharvesting, deforestation, successive wildfires and prolonged droughts have substantially decreased their production in the last decades (Moreno-Arroyo et al. 2005; Honrubia et al. 2006; Reyna 2007). As a consequence of this decline, establishing plantations of inoculated tree seedlings, compatible with Tuber spp., has allowed their culture (Meotto \& Bassi 1994; Chevalier \& Frochot 1997; Reyna \& Colina 2007; Bencivenga et al. 2009; Benucci et al. 2012b; Zambonelli et al. 2015).

Tuber melanosporum was first cultivated in France in the $19^{\text {th }}$ century (Olivier et al. 1996; Reyna \& García-Barreda 2014) and it is currently cultivated worldwide, mainly in regions with Mediterranean-like climate (Reyna \& GarcíaBarreda 2014). More recently, other Tuber species have also been successfully cultivated, such as Tuber aestivum and its ecotype T. uncinatum, Tuber borchii and the Tuber indicum complex (Chevalier \& Frochot 1997; Zambonelli et al. 2000; Hu et al. 2005). Much effort but without success has been devoted to T. magnatum (Gregori 2007; Bencivenga et al. 2009; Zambonelli et al. 2015). The failure of T. magnatum cultivation is partly due to the poor scientific knowledge gathered for this truffle during the past few decades (see Zambonelli et al. 2012b) and to the mischaracterization of $T$. magnatum in inoculated seedlings (Riccioni et al. 2016) which led to the presence of other truffle species in established plantations. In the present study we evaluate the potential of five non-native host trees species present in Chile as potential 
hosts for T. magnatum with the aim of obtaining mycorrhizal plants in controlled conditions to be used in white truffle plantations. The tested tree species are commonly found in Chile as ornamental plants and for hazelnut production (Corylus avellana) and, if found suitable host for Tuber, could eventually form wild truffle populations.

\section{MATERIALS AND METHODS}

\section{Plant material and inoculation of Seedling/cuttings}

Seeds of Quercus cerris L., Quercus robur L. and Corylus avellana L. were harvested from healthy individuals in Los Ángeles (Chile) and later stratified at $4^{\circ} \mathrm{C}$ for two months in moist conditions. Seeds were then superficially sterilized with $10 \%$ sodium hypochlorite solution for $5 \mathrm{~min}$ and sown in a Styrofoam seedbed filled with a vermiculite-based substrate. Cuttings of Populus nigra L. and Salix caprea L. were obtained from the field form healthy trees growing in the field. Cuttings were then asexually propagated in a greenhouse in plastic pots filled with river sand (particle size of 2-3 mm). The sand was previously autoclaved at $121{ }^{\circ} \mathrm{C}$ for $1 \mathrm{~h}$ during three consecutive days. Two months after seed germination and rooting of the cuttings, plant material was placed in $260 \mathrm{cc}$ pots filled with previously steam-sterilized composted bark of Pinus radiata D.Don. Substrate $\mathrm{pH}$ (5.9 in natural condition) was set to 7.7 adding a commercial plant supplement (Magnecal 15 Inacal Company, Copiapó, Chile) containing $\mathrm{CaCO}_{3}$ equival. $>95 \%, \mathrm{Mg} 15-18 \%, \mathrm{CaO} 31-36 \%, \mathrm{SO}_{3}<0.50 \%$, $\mathrm{K}_{2} \mathrm{O}<0.20 \%, \mathrm{Na}_{2} \mathrm{O}<0.30 \%$, and moisture $0.5 \%$. Plants were then inoculated with a Tuber magnatum spore suspension (10 spores/plant) corresponding approximately to $\sim 2 \mathrm{~g}$ of fresh previously identified ascomata, injected directly into the root system (Honrubia et al. 1995; Brundrett et al. 1996; Palazón \& Barriuso 2007; Pereira et al. 2010). A T. magnatum ascoma (Fig. 1a, b) collected in a natural truffle-ground in Piamonte, Italy (Guzmán Gastronomía SL-Spain) and identified according to Pegler et al. (1993) was used as inoculum. The gleba from the ascoma was cut and dried at room temperature, grinded and stored until inoculum production (Honrubia et al. 1995; Palazón \& Barriuso 2007; Pereira et al. 2010). A total of 25 seedlings/cuttings were inoculated for each plant species (125 plants in total). After inoculation, plants were grown for seven months in a growth chamber (photoperiod of 16/8-hours light/dark, RH $65 \% \pm 5$, and $\mathrm{T}^{\circ}=24 \pm 1^{\circ} \mathrm{C}$ ) and watered at field capacity once or twice per week, according to their developmental state. After the culture period, the mycorrhizal status of the plants was evaluated following previous protocols (Donnini 2005; Palazón \& Barriuso 2007). We carefully extracted segments of long roots with adhering short roots from three different depths of the root system of each plant (proximally, intermediately, and distally in relation to the root collar). Roots were then cut in segments of 2 to 3 $\mathrm{cm}$ long. Fifteen inoculated and 15 control seedlings of each plant species were evaluated. Six hundred root tips, randomly selected from these segments, were screened under a dissecting microscope for mycorrhizal formation. The results were expressed in percent of mycorrhizal root tips.

IDENTIFICATION OF ECTOMYCORRHIZAE BY MORPHOLOGICAL FEATURES Fresh mycorrhizal root tips were observed under a dissecting microscope (Olympus SZ2-ILST) and a compound microscope (Olympus CX32) and documented by micro-photography using a Moticam 20002.0 Mpixel digital camera. Morphological and anatomical features such as color and surface structures of the mycorrhizae, as well as shape of cystidia and mantle layers, were determined according to Agerer $(1986,1991)$ and compared with reference descriptions of $T$. magnatum ectomycorrhizae (Zambonelli et al. 1993; Meotto \& Bassi 1994; Rubini et al. 2001; Mello et al. 2001). Line drawings of diagnostic details were made with a Leitz Dialux compound microscope, equipped with a camera lucida drawing device at $\times 100$ magnification of water-mounted, fresh specimens. Selected reference specimens corresponding to individual ectomycorrhizae were preserved in $2 \%$ CTAB at $4{ }^{\circ} \mathrm{C}$ for subsequent molecular analysis.

\section{MoleCUlar IDENTIFICATION OF ECTOMYCORRHIZAE}

Three to five mycorrhizae previously assigned to T. magnatum based on morphological characteristics were randomly selected from C. avellana, Q. cerris and Q. robur roots systems. The same number of root tips were randomly selected from P. nigra and S. caprea roots for molecular analyses. Genomic DNA was isolated using the E.Z.N.A. Fungal DNA miniprep kit (Omega Bio-Tek, Doraville, GA, USA) without mercaptoethanol. Polymerase chain reaction (PCR) was performed using PuReTaq Ready-to-Go PCR beads (GE Healthcare, Little Chalfont, Buckinghamshire, UK). The internal transcribed spacer region (ITS) of the nuclear ribosomal DNA was amplified using the fungal specific primer ITS1F (Gardes and Bruns 1993) and the eukaryotic primer ITS4 (White et al. 1990), following cycling conditions proposed by Martín \& Winka (2000). A positive control consisting of DNA from a T. magnatum ascoma and a negative control without DNA were included. Amplicons were visualized in $2 \%$ agarose gels stained with SYBR ${ }^{\circledR}$ safe (Invitrogen, Eugene, OR, USA) under visible light. PCR products were then cleaned using the E.Z.N.A. ${ }^{\circledR}$ Cycle-Pure kit (Omega Bio-Tek) and sequenced bidirectionally. Sequences were edited with Sequencher v. 4.2 (Gene Codes Corp., Ann Arbor, MI, USA). The identification 
of the sequences was performed through BLAST searches in GenBank (Altschul et al. 1990). The obtained ITS sequences were included in GenBank under the accession numbers MG992594, MG992595 and MG992596.
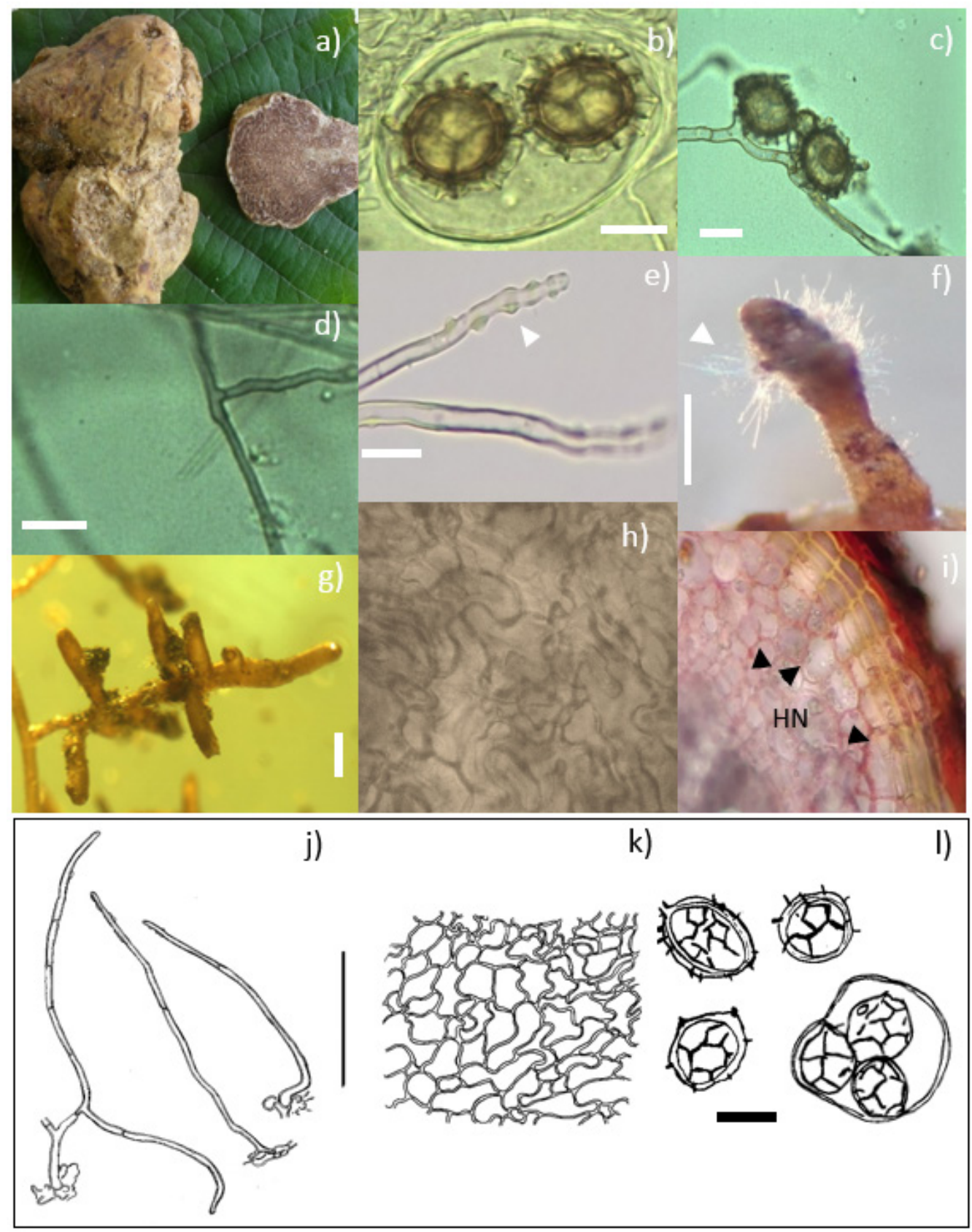

FIGURE 1. a) Tuber magnatum ascocarps, b) Asci and spores of T. magnatum (bar= $20 \mu \mathrm{m}$ ), c) Germinating spores of T. magnatum (bar $=20$ $\mu \mathrm{m})$, d) Segment of a cystidium with orthogonal ramification (bar $=20 \mu \mathrm{m})$, e) Colourless emanating hyphae with crystals $(\mathrm{bar}=10 \mu \mathrm{m})$, f) Monopodial pinnate ectomycorrhizal (bar= $0.5 \mathrm{~mm}$ ), g) Old ectomycorrhizae with no cystidia (bar= $0.5 \mathrm{~mm}$ ), h) Outer layer of fungal mantle in plain view with epidermoid-pseudoparenchymatous cell pattern, i) Root cross section and Hartig net (HN, arrowhead), j-k) Diagnostic details of ectomycorrhizae formed by T. magnatum and Q. cerris (bar $=50 \mu \mathrm{m}), \mathrm{j}$ ) Large cystidium, k) Outer layer of fungal mantle), and I) Spores (bar $=20 \mu \mathrm{m})$. / a) Ascocarpos de Tuber magnatum, b) Ascas y esporas de T. magnatum (barra= $20 \mu \mathrm{m})$, c) Esporas de T. magnatum germinando (barra $=20 \mu \mathrm{m}$ ), d) Segmentos de un cistidio con ramificación ortogonal (barra $=20 \mu \mathrm{m}$ ), e) Hifas incoloras emanando con cristales (barra $=10 \mu \mathrm{m}$ ), f) Ectomicorriza pinnada monopodial (barra = 0,5 mm), g) Ectomicorriza vieja sin cistidios (barra $=0,5 \mathrm{~mm}$ ), h) Capa externa del manto fúngico con patrón celular epidermoide-seudoparenquimatoso, i) Sección transversal de la raíz y red de Hartig (HN, flecha), j-k) Detalles diagnósticos de la ectomicorriza formada por T. magnatum y Q. cerris (barra $=50 \mu \mathrm{m}$ ), j) Cistidios grandes, k) Capa externa del manto fúngico), y I) Esporas (barra $=20 \mu \mathrm{m}$ ). 


\section{Statistical analysis}

Mycorrhizal colonization levels were compared among hosts by one-way ANOVA, and significant differences between them were determined using a Tukey test $(p<0.05)$ for multiple comparisons (Steel \& Torrie, 1989). Analyses were performed using the software STATISTICA 6.0 (Statsoft, USA).

\section{RESULTS}

Three months after inoculation with a T. magnatum spore solution, we detected the presence of mycelium of this belowground ascomycetes only in the root systems of specimens from Quercus and Corylus; we found germinated spores and growing mycelia with a simple septum and a branching pattern at approximately a right angle $\left(90^{\circ}\right)$ adjacent to the septum (Fig. 1c, d) with presence of crystals (Fig. 1e). Five months after inoculation, mycorrhizal structures typical of Tuber species were observed in secondary fine roots in Q. cerris. Ectomycorrhizae of T. magnatum were unbranched (simple, straight mycorrhiza, Fig. 1f) with infrequent pinnate monopodial structures (Fig. 1g), with or without cystidia. Young structures were light-brown/amber in color, turning red-brown when mature. Smooth surface, sometimes with hyphae, branching in approximately $90^{\circ}$ with rounded tips of 1-2.5 mm long and 0.1-0.3 mm wide. Pseudoparenchymatous and epidermoid mantle formed by long cells with rounded ends (Fig. 1h, k). Hartig net extended to the third layer of cortical cells in the root (Fig. 1i). Seven months after inoculation, we observed ectomycorrhizae of T. magnatum in Q. cerris, Q. robur and C. avellana, but we did not find signs of root colonization by T. magnatum in P. nigra and S. caprea. We found the highest colonization levels in Q. cerris with a
$32 \%$ of the root tips showing T. magnatum ectomycorrhizae, followed by Q. robur (21\%) and C. avellana (17\%) (Fig. 2). The ITS sequences obtained from the ectomycorrhizae in both oak and hazel confirmed their identity as Italian white truffle, showing maximum similarity with $T$. magnatum sequences from GenBank. We found ectomycorrhizas of Geospora sp. in the root system of P. nigra and S. crapea, but we did not observe symbiotic association with T. magnatum.

Substrate organic material was $31.5 \%$. Once substrate $\mathrm{pH}$ was corrected (5.9 to 7.7), we measured a decrease in $\mathrm{N}$ and in the $\mathrm{C} / \mathrm{N}$ ratio. We also observed an increase in $\mathrm{P}, \mathrm{K}, \mathrm{Ca}, \mathrm{Mg}$ and in electric conductivity from 0.13 to $0.56 \mathrm{dSm}^{-1}$ (Table 1).

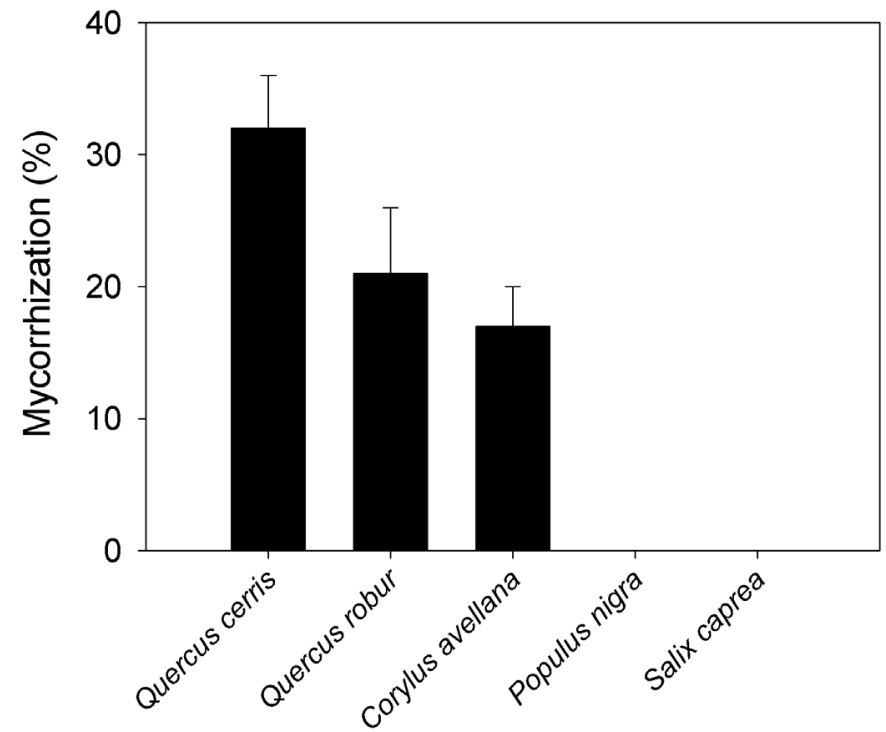

Figure 2. Percentage of mycorrhizal roots in Q. cerris, Q. robur, C. avellana, P. nigra and S. caprea nurse plants. / Porcentaje de raíces micorrizadas en plantas nodrizas de Q. cerris, Q. robur, C. avellana, P. nigra y S. caprea.

TABLE 1. Chemical properties of pine bark substrate used for inoculation of woody plants with T. magnatum before and after liming. $\mathrm{OM}=$ organic matter; $\mathrm{EC}=$ electric conductivity. / Propiedades químicas del sustrato de corteza de pino usado para la inoculación de plantas leñosas con T. magnatum antes y después de aplicar cal. OM = materia orgánica; EC = conductividad eléctrica.

\begin{tabular}{lccccccccc}
\hline Liming & $\mathrm{pH}$ & $\mathrm{OM}(\%)$ & Total Nitrogen (\%) & $\mathrm{P}_{2} \mathrm{O}_{5}(\%)$ & $\mathrm{K}_{2} \mathrm{O}(\%)$ & $\mathrm{CaO}(\%)$ & $\mathrm{MgO}(\%)$ & $\mathrm{C} / \mathrm{N}$ & $\mathrm{EC} \mathrm{dS} \mathrm{m}^{-1}$ \\
\hline Before & 5.9 & 31.5 & 0.60 & 0.17 & 0.19 & 1.42 & 0.84 & 38.3 & 0.13 \\
After & 7.7 & 31.5 & 0.44 & 0.20 & 0.24 & 7.02 & 1.43 & 28.5 & 0.56 \\
\hline
\end{tabular}

\section{DISCUSSION}

The most important technological advance in truffle cultivation has been the large scale production of quality inoculated plant seedlings (Chevalier \& Pargney 2014). Modern truffle cultivation is based on planting high quality colonized plants grown under controlled conditions in greenhouses into locations with suitable soils and climates (Zambonelli et al. 2010, 2015). The spore inoculation technique used in this study is the most commonly used method for producing Tuber-colonized plants because of its simplicity and the impossibility of obtaining enough mycelium 
due to its slow growth in Tuber (Mello et al. 2006; Zambonelli et al. 2010; Hall \& Zambonelli 2012). Mycelium as inoculum is only used for a reduced group of truffle species (Zambonelli et al. 2010; Lancellotti et al. 2014; lotti et al. 2016) which could allow to select the fungal strains adapted to specific climatic, edaphic conditions and hosts (Zambonelli et al. 2010, 2015). Tuber magnatum produces the world's most expensive truffle (Murat et al. 2005; Mello et al. 2006; Zambonelli et al. 2012b; lotti et al. 2014; Riccioni et al. 2016). This species is distinct from other Tuber species for the unique aroma of its ascomata, its limited distributional range, and the difficulties of its cultivation (Mello et al. 2001; Riccioni et al. 2016). Much effort has been devoted to the artificial culture of $T$. magnatum, but without success (Gregori 2007; Bencivenga et al. 2009; Benucci et al. 2012a).

To our knowledge, this is the first successful artificial mycorrhization with T. magnatum in South America, and Chile in particular. Five months after inoculation Quercus and Corylus seedlings showed T. magnatum ectomycorrhizae (between 17-32\%) without detectable presence of other mycorrhizal fungi colonizing the same roots systems. These three species have been previously described as hosts of $T$. magnatum (Mischiati \& Fontana 1993; Meotto \& Bassi 1994; Bencivenga et al. 2009). Unlike other edible truffle species, the mycorrhization with $T$. magnatum is a very difficult and delicate process, usually hard to reproduce in different sites/ conditions (Rubini et al. 2001; Zambonelli et al. 2012a; Benucci et al. 2012a; Riccioni et al. 2016). In fact, Mello et al. (2001) suggests that T. magnatum has a lower ability to form ectomycorrhizas compared to other Tuber species, possibly related to low spore germination (Gregori 2002; Hall \& Zambonelli 2012; Murat 2015). However, three months after inoculation, we detected germinating spores of T. magnatum in the root system of the plants (see Fig. 1c). Riccioni et al. (2016) state that difficulties in obtaining genuine T. magnatum ectomycorrhizas on nursery-inoculated host plants might result from the scarce competitive ability of this fungus and/or from the ability for sustaining these structures on their hosts over several months at field conditions. Few studies obtained ectomycorrhizae of T. magnatum in controlled conditions (Mischiati \& Fontana 1993; Glamoclija 2000; Mello et al. 2001; Rubini et al. 2001). We obtained higher mycorrhizal levels (17 and 32\%) that Mischiati \& Fontana (1993) for Tilia cordata $(12,5 \%)$, Q. robur (11\%) and Corylus avellana (16,5\%) using mycelium as inoculum. These are relatively low compared to previous reports on other Tuber species. For example, T. borchi can reach colonizations levels of $62 \%$, T. aestivum of $42 \%$, and T. melanosporum of $74 \%$ in controlled conditions (Benucci et al. 2011; Benucci et al. 2012b; Pereira et al. 2013). However, due to the technical difficulties in T. magnatum cultivation, the obtaining of mycorrhizal plant can be considered a success, despite the relatively low percentage.

The optimum level of mycorrhizal colonization in the roots mostly depends on the climatic and soil characteristics of the plantation site, which affect competitiveness, extent and rate of colonization of the inoculated species (lotti et al. 2012a). Zambonelli et al. (2005) showed that a 30\% initial rate of root colonization with $T$. aestivum reached values of $50-70 \%$ in mycorrhizal seedlings after 5 years when planted in a suitable soil. Tuber magnatum is a particularly intriguing ectomycorrhizal fungus: it produces ectomycorrhizae in controlled conditions (lotti et al. 2012b), but they are rarely found in the field in productive truffle-grounds (Murat et al. 2005; Bertini et al. 2006; Mello et al. 2006; Zambonelli et al. 2012b; lotti et al. 2014). Tuber magnatum mycorrhizae area also absent in natural productive areas (Leonardi et al. 2013; Salerni et al. 2014) and when present, mycorrhization percentage in usually below 5\% (Murat et al. 2005; Bertini et al. 2006). In fact, the mycorrhizas of this truffle seem to disappear when the plants are transplanted in the field (Hall et al. 2007). In contrast, other species of Tuber such as $T$. rufum, T. brumale, T. maculatum and T. borchii can achieve a mycorrhization of 9,6 to 48,9\% in the field (Murat et al. 2005; Bertini et al. 2006; lotti \& Zambonelli 2006).

The Italian white truffle can forms ectomycorrizae in roots of poplars, willows, oaks, aspen, alder and hazelnut (Meotto et al. 1992; Donnini et al. 2000; Murat et al. 2005; Bencivenga et al. 2009; Luigi et al. 2010). However, seven months after inoculation, seedlings of the Salicaceae species Populus nigra and Salix caprea did not show colonization of T. magnatum. In our study, cuttings of $P$. nigra and S. caprea developed highly lignified root systems, which were probably not suitable for the mycorrhizal association with T. magnatum. Additionally, in these two genera, ectomycorrhizas of Geopora were found. Fungal species such as Sphaerosporella brunnea and Pulvinula constellatio can be frequent contaminant in the production of mycorrhizal plants inoculated with T. magnatum as well as other truffle species such as T. maculatum and T. borchii (Amicucci et al. 2001; Bertini et al. 2006; Riccioni et al. 2016). Inoculum quality is one of the most important requirements when Tuber infected plants are produced (Zambonelli et al. 2010). When large quantities of ascomata are used to prepare inoculum, operators may accidentally incorporate less valuable species of white truffles which can then become established on the host plants (Zambonelli et al. 2010; Murat et al. 2016). Tuber magnatum mycorrhizas can be barely distinguished morphologically from those of other related white truffles (Mello et al. 2001), therefore DNA-base identification is needed (Riccioni et al. 2016). The introduction of molecular methods for the identifications has allowed to 
detect less valuable Tuber species such as T. maculatum and T. borchii, in T. magnatum-inoculated plants (lotti et al. 2012a; Zambonelli et al. 2015).

The type of soil used to grow inoculated plants affects the rate of root colonization by target fungal species and potential contaminants (lotti et al. 2012a). Various substrate types have been tested during the development of truffle culture, ranging from natural soil from truffle woodlands to different types and mixtures of natural and artificial components such as soil, peat, perlite, vermiculite, sand, dolomite, and varieties of compost (Palazon \& Barriuso 2007; lotti et al. 2012a). However, specific details about the composition of the potting mixes, inoculum amounts, amendments, and greenhouse conditions vary among nurserymen, and most remain a trade secret (Hall et al. 2003). The results of our assay confirm that compost of $P$. radiata bark, a cheap and available product in forestry industry, is an adequate substrate after an adjustment of its natural $\mathrm{pH}$ of 5.9 by application of lime such as Magnecal 15 which consists mostly of $\mathrm{CaCO}_{3}$ and other mineral components that add important micronutrients during the nursery phase of the inoculated seedlings. $P$. radiata plantations occupy a large area in Central-South Chile and this could be a potentially interesting use for its bark. The incomplete composting of the pine bark may have a negative impact on seed germination and seedling growth and thus hamper the establishment of mycorrhizal symbiosis but this does not seem to be the case in our study where the substrate $\mathrm{pH}$ was adjusted to 7.7 , suitable for synthesis of $T$. magnatum mycorrhizae. In general, truffle species prefer low organic matter mixtures supplemented with calcium carbonate components (Pruett et al. 2009) to raise $\mathrm{pH}$ to $~ 8.0$ (lotti et al. 2012a). Organic matter content in the substrate used here was $31.5 \%$, which can be considered relatively high. In Europe, soils from areas where T. magnatum naturally occur have been used for the cultivation of mycorrhizal plants (lotti et al. 2012a), with the associated economic and environmental costs that this practice implies. These natural calcareous soils in Italy have a pH close to 8 and organic matter content range from close to 2.5 to $3 \%$ (Bencivenga $\&$ Baciarelli 2012). Conductivity reflects the concentration of soil solution salts in the substrate; a high conductivity may be due to the substrate material but also to excessive fertilization, which can negatively affect plant performance and mycorrhizal formation. Low levels of this parameter are recommended for truffle culture; in fact, natural truffle grounds have not been found in saline or chalky soils (GarcíaMontero et al. 2007).

The artificial culture of truffles, especially T. melanosporum, is common in different parts of the world (Hall et al. 2007; Chevalier \& Pargney 2014; Reyna \& García-Barreda 2014;
Zambonelli et al. 2015; Murat et al. 2016; Zambonelli et al. 2017). In Chile, there are close to 400 ha of T. melanosporum currently in production. The new challenge for the country is the introduction, and future production of other Tuber species, especially those with high demand and economic value in international markets. Here, we contribute to the understanding of the controlled mycorrhization of tree species with $T$. magnatum, using a composted $P$. radiata bark as a substrate, after $\mathrm{pH}$ adjustments though liming. Additionally, we described the macroscopic and microscopic characteristics of the mycorrhizal association between T. magnatum and $Q$. cerris. Future studies should test longer viverization periods to increase mycorrhization percentage. Additionally, field assays are required to evaluate the behavior of the mycorrhizal fungi in natural soils with artificially corrected $\mathrm{pH}$. This information could be used in the future domestication and production of white truffle, and other edible truffles, in Chile. Additionally, Quercus, Populus and Salix species are commonly used as ornamental plants and urban trees and are common in rural settings. These species have been present in Chile for over 100 years and are naturalized. C. avellana plantations are also present in Central-South Chile. It should be taken into account that Tuber spores (or other types of inoculum) could be dispersed from production sites into compatible host trees in urban or rural areas. The ecological consequences of this potential formation of wild populations of truffles should be further studied. However, due to the host-specificity and the $\mathrm{pH}$ requirements of Tuber magnatum we hypothesize that an ecological impact on native plants and/or fungi is unlikely. This truffle, as stated above, require basic soils which are not usually found in Chile.

\section{ACKNOWLEDGMENTS}

The authors acknowledge funding from INNOVA Bío Bío No. 05-B1-344-L6 project. Our posthumous thanks to Dr. M. Honrubia for its active participation and constant support during the course of this project in Chile.

\section{REFERENCES}

Agerer, R. 1986. Studies on ectomycorrhizae. II. Introductory remarks on their characterizations and identification. Mycotaxon 26: 473-492.

Agerer, R. 1991. Characterization of ectomycorrhiza. In: Norris, J.R., Read, D.J., Varma, A.K. (eds.), Methods in microbiology: techniques for the study of mycorrhiza, pp. 25-73. Academic Press, London, UK. 
Altschul, S.F., Gish, W., Miller, W., Myers, E.W., Lipman, D.J. 1990. Basic local alignment search tool. Journal of Molecular Biology 215(3): 403-410.

Amicucci, A., Zambonelli, A., Giomaro, G., Potenza, G., Stocchi, V. 1998. Identification of ectomycorrhizal fungi of the genus Tuber by species-specific ITS primers. Molecular Ecology 7: 273-277.

Amicucci, A., Zambonelli, A., Guidi, C., Stocchi, V. 2001. Morphological and molecular characterization of Pulvinula constellation ectomycorrhizae. FEMS Microbiology Letters 194: 121-125.

Bencivenga, M., Baciarelli, L. 2012. Manuale di Tartuficoltura. Esperienze di coltivazione dei tartufi in Umbria. Regione Umbria. Assessorato Regionale Agricoltura e Foreste, Italy. 127 pp.

Bencivenga, M., Massimo, G., Momizia, D., Baciarelli-Falini, L. 2009. The cultivation of truffles in Italy. Acta Botanica Yunnanica 16: 21-28.

Benucci, G., Bonito, G., Baciarelli-Falini, L., Bencivenga, M. 2011. Mycorrhization of pecan trees (Carya illinoinensis) with commercial truffle species: Tuber aestivum Vittad. and Tuber borchii Vittad. Mycorrhiza 22: 383-392. doi: 10.1007/s00572-011-0413-z.

Benucci, G., Bonito, G., Baciarelli-Falini, L., Bencivenga, M., Donnini, D. 2012a. Truffles, timber, food, and fuel: sustainable approaches for multi-cropping truffles and economically important plants. In: Zambonelli, A., Bonito, G. (eds.), Edible Ectomycorrhizal Mushrooms, Soil Biology vol. 34, pp. 265-267. Springer-Verlag, Berlin, Heidelberg, Germany.

Benucci G, Bonito G, Baciarelli L, Bencivenga M, Donnini D. 2012b. Mycorrhizal inoculation of pecan seedlings with some marketable truffles. Acta Mycologica 47: 179-184.

Bertini, L., Rossi, I., Zambonelli, A., Amicucci, A., Sacchi, A., Cecchini, M., Gregori, G., Stocchi, V. 2006. Molecular identification of Tuber magnatum ectomycorrhizae in the field. Microbiology Research 161: 59-64. doi: 10.1016/j. micres.2005.06.003

Bonito, G., Gryganskyi, A.P., Trappe, J.M., Vilgalys, T. 2010. A global meta-analysis of Tuber ITS rDNA sequences: species diversity, host associations and long-distance dispersal. Molecular Ecology 19: 4994-5008. doi: org/10.1111/j.1365-294X.2010.04855.x.

Bonito, G., Smith, M.E., Nowak, M., Healy, R.A., Guevara, G., Cázares, E., Kinoshita, A., Nouhra, E.R., Domínguez, L.S., Tedersoo, L., Murat, C. 2013. Historical biogeography and diversification of truffles in the Tuberaceae and their newly identified southern hemisphere sister lineage. PLoS ONE 8: e52765. doi: 10.1371/journal.pone.0052765.

Bonito, G., Smith, M.E. 2016. General Systematic Position of the Truffles: Evolutionary Theories. In: Zambonelli, A., Iotti,
M., Murat, C. (eds.), True Truffle (Tuber Spp.) in the World: Soil Ecology, Systematics and Biochemistry, pp. 3-18. Springer International Publishing, Cham, Switzerland.

Brundrett, M., Bougher, N., Grove, T., Malajczuk, N. 1996. Working with mycorrhizas in forestry and agriculture. ACIAR, Canberra.

Chevalier, G., Frochot, H. 1997. La truffe de Bourgogne (Tuber uncinatum Chatin). Éditions Pétrarque, Levallois-Perret, France. $257 \mathrm{pp}$.

Chevalier, G., Pargney, J.C. 2014. Empirical or rational truffle cultivation? It is time to choose. Forest Systems 23(2): 378-384. doi: /10.5424/fs/2014232-04964.

De Miguel, A.M., Reyna, S. 2007. Fundamentos de micología, Tuberaceas. In: Reyna S. (ed.), Truficultura. Fundamentos y técnicas, pp. 74-106. Mundi-Prensa, Madrid, Spain.

Donnini, D. 2005. Controllo morfologico e certificazione delle piante micorrizate. Seminario sullo stato attuale della tartuficoltura italiana, Spoleto-Norcia, pp. 22-27.

Donnini, D., Bencivenga, M., Baciarelli-Falini, L. 2000. Risultati di esperienze pluriennali nella coltivazione di Tuber magnatum Pico in Umbria. Micologia Italiana 3: 33-39.

García-Montero, L.G., Casermeiro, M.A., Hernando, I., Hernando, J. 2007. Effect of active carbonate, exchangeable calcium, and stoniness of soil on Tuber melanosporum carpophore production. New Zealand Journal of Crop and Horticultural Science 35: 139-146.

Gardes, M., Bruns, T.D. 1993. ITS primers with enhanced specificity for basidiomycetes application to the identification of mycorrhizae and rusts. Molecular Ecology 2: 113-118.

Glamočlija, J. 2000. Mycorrhization of oac and hazel trees with different species of the genus Tuber. Archives of Biological Sciences 52: 109-114.

Gregori, G. 2002. Problems and expectations with the cultivation of Tuber magnatum. In: Hall, I.R., Wang, Y., Danell, E., Zambonelli, A. (eds.), Edible mycorrhizal mushrooms and their cultivation. Proceedings of the $2^{\text {nd }}$ international conference on edible mycorrhizal mushrooms, New Zealand Institute for Crop \& Food research, New Zealand, CD-ROM.

Gregori, G. 2007. Principales aspectos de la trufa y la truficultura en Italia. In: Reyna, S. (ed.), Truficultura Fundamentos y técnicas, pp: 433-464. Mundi-Prensa, Madrid, Spain.

Hall, I.R., Yun, W., Amicucci, A. 2003. Cultivation of edible ectomycorrhizal mushrooms. Trends in Biotechnology 21: 433-438.

Hall, I., Brown, G.T., Zambonelli, A. 2007. Taming the truffle: the history, lore, and science of the ultimate mushroom. Timber, Portland, OR, USA. 304 pp.

Hall, I., Zambonelli, A. 2012. Laying the foundations. In: Zambonelli A, Bonito GM, (eds.), Edible Ectomycorrhizal Mushrooms, Soil Biology, vol. 34, pp. 3-16. Springer- 
Verlag, Berlin, Heidelberg, Germany.

Honrubia, M., Torres, P., Díaz, G., Morte, A. 1995. Biotecnología forestal: Técnicas de micorrización y micropropagación de plantas. Secretariado de Publicaciones, Universidad de Murcia, Murcia, Spain. 85 pp.

Honrubia, M., Fernández, A., Moya, D., González, A., De las Heras, J. 2006. Potencialidad de la trufa negra (Tuber nigrum Bull.) en la provincia de Albacete. Montes 83: 35-40.

Hu, H.T., Wang, Y., Hu, B.Y. 2005. Cultivation of Tuber formosanum on limed soil in Taiwan. New Zealand Journal of Crop and Horticultural Science 33: 363-366. doi: 10.1080/01140671.2005.9514371.

lotti, M., Zambonelli, A. 2006. A quick and precise technique for identifying ectomycorrhizas by PCR. Mycological Research 110: 60-65. doi: 10.1016/j. mycres.2005.09.010.

lotti, M., Pattoni, F., Zambonelli, A. 2012a. Techniques for host Plant inoculation with truffles and other edible ectomycorrhizal mushrooms. In: Zambonelli, A., Bonnito, G. (eds.), Edible Ectomycorrhizal Mushrooms, Soil Biology 34, pp. 145-161. Springer-Verlag, Berlin, Heidelberg, Germany.

lotti, M., Leonari, F., Oddis, M., Salerni, E., Zambonelli, A. 2012b. Development and validation of a real-time PCR assay for detection and quiantification of Tuber magnatum in soil. BMC microbiology 6: 12-93. doi: 10.1186/1471-218012-93.

Iotti, M., Leonardi, M., Lancellotti, E., Salerni, E., Oddis, M., Leonardi, P., Perini, C., Pacioni, G., Zambonelli, A. 2014. Spatio-Temporal Dynamic of Tuber magnatum Mycelium in Natural Truffle Grounds. PLoS ONE 9(12): e115921. doi: 10.1371/journal.pone.0115921.

Iotti, M., Piattoni, F., Leonardi, P., Hall, I., Zambonelli, A. 2016. First evidence for truffle production from plants inoculated with mycelial pure cultures. Mycorrhiza 26: 793-798. doi: 10.1007/s00572-016-0703-6.

Lancellotti, E., lotti, M., Zambonelli, A., Franceschini, A. 2014. Characterization of Tuber borchii and Arbutus unedo mycorrhizas. Mycorrhiza 24: 481-486. doi: 10.1007/ s00572-014-0564-9.

Leonardi, M., lotti, M., Oddos, M., Lalli, G., Pacioni, G., Leonardi, P., Maccherini, S., Perini, C., Salerni, E., Zambonelli, A. 2013. Assessment of ectomycorrhizal fungal communities in the natural habitats of Tuber magnatum (Ascomycota, Pezizales). Mycorrhiza 23: 349-358. doi: 10.1007/ s00572-012-0474-7.

Luigi, G., Domizia, D., Bencivenga, M. 2010. Tuber magnatum: alcuni esempi productivi di tartufaie coltivate in Italia. Terzo Congreso Internazionale di Spoleto sul Tartufo. Comunità Montana dei Monti Martani Serano e Subasio, pp. 741-749. Umbria, Italy.
Martín, M.P., Winka, K. 2000. Alternative methods of extracting and amplifying DNA from lichens. Lichenologist 32: 189196. doi: 10.1006/lich.1999.0254.

Mello, A., Fontana, A., Meotto, F., Comandini, O., Bonfante, P. 2001. Molecular and morphological characterization of Tuber magnatum mycorrhizas in a long-term survey. Microbiology Research 155: 279-284.

Mello, A., Murat, C., Bonfante, P. 2006. Truffles: much more than a prized and local fungal delicacy. FEMS Microbiology Letters 260: 1-8. doi: 10.1111/j.15746968.2006.00252.x.

Meotto, F., Carraturo, P., Dana, M. 1992. Valutazione in pieno campo e in serra della competitività di Sphaeroporella brunnea con Tuber magnatum. L'Informatore Agrario 47: 73-78.

Meotto, F., Bassi, R. 1994. Guida illustrata coltivazione e cerca del tarfufo. Supplemento $N^{\circ} 6$ di Vita in Campagna. Italia. $26 \mathrm{p}$.

Mischiati, P., Fontana, A. 1993. In vitro culture of Tuber magnatum mycelium isolated from mycorrhizas. Mycological Research 97(1): 40-44.

Moreno-Arroyo, B., Gómez, J., Pulido, E. 2005. Tesoros de nuestros montes. Trufas de Andalucía. Consejería de Medio Ambiente, Junta de Andalucía, Córdoba, Spain. $352 \mathrm{pp}$.

Murat, C. 2015. Forty years of inoculating seedlings with truffle fungi: past and future perspectives. Mycorrhiza 25: 7781. doi: 10.1007/s00572-014-0593-4.

Murat, C., Vizzini, A., Bonfante, P., Mello, A. 2005. Morphological and molecular typing of the below-ground fungal community in a natural Tuber magnatum truffle-ground. FEMS Microbiology Letters 245: 307-313. doi: 10.1016/j. femsle.2005.03.019.

Murat, C., Bonneau, L., De la Varga, H., Olivier, J.M., Sandrine, F., Le Tacon, F. 2016. Trapping truffle production in holes: a promising technique for improving production and unravelling truffle life cycle. Micologia Italiana 45: 47-52. doi: 10.6092/issn.2531-7342/6346.

Olivier, J.M., Savignac, J.C., Sourzat, P. 1996. Truffe et Trufficulture. Editions Fanlac, Périgueux, France. 263 pp.

Palazón, C., Barriuso, J. 2007. Vivero y producción de plantas micorrizadas. In: Reyna, S. (ed.), Truficultura: Fundamentos y técnicas, $2^{a}$ edición, pp. 209-236. Ediciones MundiPrensa, Spain.

Paolocci, F., Rubini, A., Riccioni, C., Arcioni, S. 2006. Reevaluation of the Life Cycle of Tuber magnatum. Applied and Environmental Microbiology 73: 2390-2393. doi: 10.1128/AEM.72.4.2390-2393.2006.

Pegler, D.N., Spooner, B.M., Young, T.W.K. 1993. British Truffles: A Revision of British Hypogeous Fungi. Kew Royal Botanic Garden, London, UK. 224 pp. 
Pereira, G., Chávez, D., Machuca, A., Suz, L.M., Honrubia, M. 2010. Trufas: Alternativa de cultivo para agroforestadores de la Provincia del Bío Bío. Universidad de Concepción, Chile. 46 pp.

Pereira, G., Palfner, G., Chávez, D., Suz L.M., Machuca, A., Honrubia, M. 2013. Using common mycorrhizal networks for controlled inoculation of Quercus spp. with Tuber melanosporum: the nurse plant method. Mycorrhiza 23: 373-380. doi: 10.1007/s00572-013-0480-4.

Pruett, G.E., Bruhn, J.N., Mihail, J.D. 2009. Greenhouse production of Burgundy truffle mycorrhizae on oak roots. New Forest 37: 43-52. doi: 10.1007/s11056-008-9108-5.

Reyna, S. 2000. Trufas, truficultura y selvicultura trufera. Ediciones Mundi-Prensa, Barcelona.

Reyna, S. 2007. Sostenibilidad de la truficultura: aspectos ecológicos, económicos y sociales. In: Reyna, S. (ed.), Truficultura: Fundamentos y técnicas, pp. 51-73. MundiPrensa, Madrid, Spain.

Reyna, S., Colina, C. 2007. Truficultura. In: Truficultura: Reyna, S. (ed.), Truficultura: Fundamentos y técnicas, pp. 237-276. Mundi-Prensa, Madrid, Spain.

Reyna, S., De Miguel, A. 2007. Las micorrizas. Ciclo biológico de la trufa. In: Reyna, S. (ed.), Truficultura: Fundamentos y técnicas, pp. 107-152. Mundi-Prensa, Madrid, Spain.

Reyna, S., García-Barreda, S. 2014. Black truffle cultivation: a global reality. Forest Systems 23(2): 317-328. doi: $10.5424 / f s / 2014232-04771$.

Riccioni, C., Rubini, A., Belfiori, B., Paolocci, F. 2016. Tuber magnatum: The Special One. What Makes It so Different from the Other Tuber spp.? In: Zambonelli, A., lotti, M., Murat, C. (eds.), True truffle (Tuber spp.) in the world: soil ecology, systematics and biochemistry. Soil biology 47 , pp: 87-103. Springer, Switzerland.

Rubini, A., Paolocci, F., Granetti, B., Arcioni, S. 2001. Morphological characterization of molecular-typed Tuber magnatum ectomycorrhizae. Mycorrhiza 11: 179-185. doi: 10.1007/ s005720100116.

Sáez, R., De Miguel, A. 2008. La trufa. Guía de truficultura. Instituto Técnico y de gestión Agrícola, Navarra-España. $132 \mathrm{pp}$.

Salerni, E., lotti, M., Leonardi, P., Gardin, L., Aguanno, M.D., Perini, C., Pacioni, P., Zambonelli, A. 2014. Effect of soil tillage on Tuber magnatum development in natural truffieres. Mycorriza 24(1): 79-87. doi: 10.1007/s00572-013-0543-6.

Selosse, M.-A., Faccio, G., Scappaticci, G., Bonfante, P. 2004. Chlorophyllous and achlorophyllous specimens of Epipactis microphylla (Neottieae, Orchidaceae) are associated with ectomycorrhizal septomycetes, including truffles. Microbial Ecology 47: 416-426. doi: 10.1007/ s00248-003-2034-3.

Schneider-Maunoury, L., Leclercq, S., Clément, C., Covès, H., Lambourdière, J., Sauve, M., Richard, F., Selosse, M.-A., Taschen, E. 2018. Is Tuber melanosporum colonizing the roots of herbaceous, non-ectomycorrhizal plants? Fungal Ecology 31: 59-68. doi: 10.1016/j.funeco.2017.10.004.

Steel, R., Torrie, J. 1989. Bioestadística: Principios y procedimientos, segunda edición. McGraw Hill, México. $622 \mathrm{pp}$.

White, T.J., Bruns, T., Lee, S., Taylor, J. 1990. Amplification and direct sequencing of fungal ribosomal RNA genes for phylogenetics. In: Innis, M.A., Gelfand, D.H., Sninsky, J.J., White, T.J. (eds.), PCR protocols: A guide to methods and applications, pp. 315-322. Academic Press, New York, USA.

Zambonelli, A., Salomoni, S., Pisi, A. 1993. Caratterizzazione anatomo-morfologica delle micorrize di Tuber spp. su Quercus pubescens Willd. Micologia Italiana 3: 73-90.

Zambonelli, A., lotti, M., Rossi, I., Hall, I. 2000. Interactions between Tuber borchii and other ectomycorrhizal fungi in a field plantation. Mycological Research 104: 698-702.

Zambonelli, A., lotti, M., Dallavalle, E., Hall, I.R. 2005. Effect of mulching on Tuber uncinatum ectomycorrhizas in an experimental truffière. New Zealand Journal of Crop and Horticultural Science 33: 65-73. doi: 10.1080/ 01140671.2005.9514332e.

Zambonelli, A., Piattoni, F., lotti, M., Hall, I. 2010. What makes a good truffle infected tree? Österreichische Zeitschrift für Pilzkunde 19: 201-207.

Zambonelli, A., Perini, C., Pacioni, G. 2012a. Introduzione. Progetto MAGNAUM. Monitoraggio delle attività di gestione delle tartufaie naturali di Tuber magnatum risultati e consigli pratici. Progetto Interregionale di Toscana, Abruzzo, Emilia-Romagna, Molise, Italy. 86 pp.

Zambonelli, A., lotti, M., Boutahir, S., Lancellotti, E., Perini, C., Pacioni, G. 2012b. Ectomycorrhizal fungal communities of edible ectomycorrhizal mushrooms. In: Zambonelli A, Bonito GM, (eds). Edible Ectomycorrhizal Mushrooms, Soil Biology, vol. 34, pp. 105-124. Springer-Verlag, Berlin, Heidelberg, Germany.

Zambonelli, A., lotti, M., Hall, I. 2015. Current status of truffle cultivation: recent results and future perspectives. Micologia Italiana 44: 31-40. doi: 10.6092/issn.2465$311 X / 5593$.

Zambonelli, A., Leonardi, P., lotti, M., Hall, I. 2017. Ecological and genetic advances in the cultivation of Tuber spp. Revista Fitotecnia Mexicana 40(4): 371-377.

Received: 06.12.2019

Accepted: 21.10.2020 